Jurnal Pemberdayaan: Publikasi Hasil Pengabdian kepada Masyarakat

Vol. 3, No. 2, Agustus 2019, Hal. 199-204

ISSN: 2580-2569; e-ISSN: 2656-0542

DOI: https://doi.org/10.12928/jp.v3i2.931

\title{
Ekonomi kreatif pembuatan detergent cair dan bubuk pada kelompok PKK Kelurahan Krajan
}

\author{
Siti Fatimah ${ }^{1}$, Wiharto ${ }^{2}$, Anita Indrasari ${ }^{3}$ \\ Universitas Muhammadiyah Surakarta, Jl. A. Yani, Pabelan,Sukoharjo, Jawa Tengah ${ }^{1}$ \\ Universitas Sebelas Maret, Jl. Ir Sutami No.36 A, Surakarta, Jawa Tengah ${ }^{2}$ \\ Universitas Setia Budi, Jl. Letjen Sutoyo, Mojosongo Surakarta, Jawa Tengah ${ }^{3}$ \\ Email: sf120@ums.ac.id
}

\begin{abstract}
ABSTRAK
Ekonomi kreatif merupakan sebuah konsep ekonomi di era ekonomi baru yang mengintensifkan informasi dan kreativitas dengan mengandalkan ide dan stock of knowledge. Masyarakat yang heterogen, majemuk dan faktor Sumber Daya Manusia (SDM) menjadi faktor utama dalam kegiatan ekonomi. Masyarakat yang kondisi geografis ekonominya berada di lingkungan pusat perekonomian seperti pasar tradisional, dituntut untuk lebih kreatif, inovatif, dan sensitif tentang kondisi pangsa pasar. Kelompok Pembinaan Kesejahteraan Keluarga (PKK) Kelurahan Krajan Kabupaten Klaten berada pada kondisi sosial geografis ekonomi yang strategis dengan lingkungan pasar tradisional. Sebagian kelompok PKK ini memiliki pendapatan yang masih rendah karena tidak memiliki modal atau ketrampilan yang terbatas untuk menambah penghasilan. Mata pencahariannya antara lain adalah sebagai pedagang, pembantu rumah tangga, pengasuh anak, dan menjual minuman atau makanan. Kegiatan jual beli ini hanya berlangsung di pagi hari saja tatkala kegiatan pasar masih aktif. Pada siang atau sore sampai malam mereka tidak memilki aktifitas tambahan. Program pendampingan dan pelatihan pembuatan detergent cair dan bubuk dilakukan untuk meningkatkan taraf perekonomian dan membantu menciptakan ketentraman dalam berkehidupan. Kegiatan ini dilakukan tanpa menghilangkan pekerjaan utamanya, dan bisa dilakukan setiap saat atau ketika longgar. Metode pelaksanaan program ini adalah introduksi, pelatihan, pendampingan, dan pemantauan. Tujuan program ini adalah adanya peningkatan pendapatan kelompok PKK.
\end{abstract}

Kata kunci : pemberdayaan, PKK, ekonomi kreatif, detergen cair, detergen bubuk

\begin{abstract}
Creative economy is an economic concept in a new economic era that intensifies information and creativity by relying on ideas and stock of knowledge. Heterogeneous, pluralistic society and Human Resource (HR) factors are the main factors in economic activity. Communities whose economic geographical conditions are in the economic center environment such as traditional markets, are required to be more creative, innovative, and sensitive about market share conditions. The Pembinaan Kesejahteraan Keluarga (PKK) Group of Krajan Village, Klaten Regency is in a strategic socio-economic condition with a traditional market environment. Some of these PKK groups have low incomes because they do not have the capital or limited skills to supplement their incomes. Their livelihoods include trading, housemaid, child care, and selling drinks or food. Buying and selling activities only take place in the morning when the market activity is still active. In the afternoon or evening until the evening they do not have additional activities. The assistance and training program for making liquid and powder detergents is carried out to improve the economy and help create peace in life. This activity is carried out without losing its main work, and can be done at any time or when it is loose. The steps are introduction, training, assistance, and monitoring. Output targets to be achieved include an increase in PKK group income
\end{abstract}

Keywords : training, PKK, creative economy, liquid detergents, powder detergents 


\section{PENDAHULUAN}

Struktur perekonomian dunia mengalami transformasi dengan cepat seiring dengan pertumbuhan ekonomi, dari yang tadinya berbasis Sumber Daya Alam (SDA), kemudian menjadi berbasis Sumber Daya Manusia (SDM), dari era genetik dan ekstraktif ke era manufaktur dan jasa informasi serta perkembangan terakhir masuk ke era ekonomi kreatif (Sadilah, 2010). Untuk mendorong pengembangan ekonomi kreatif, diperlukan langkahlangkah strategis yang tepat. Ekonomi kreatif merupakan sebuah konsep ekonomi di era ekonomi baru yang mengintensifkan informasi dan kreativitas dengan mengandalkan ide dan stock of knowledge (Purnomo, 2016). Masyarakat yang heterogen, majemuk dan faktor Sumber Daya Manusia (SDM menjadi faktor utama dalam kegiatan ekonomi. Masyarakat yang kondisi geografis ekonominya berada di lingkungan pusat perekonomian seperti pasar tradisional, dituntut untuk lebih kreatif, inovatif, dan sensitif tentang kondisi pangsa pasar. Bidang ekonomi kreatif telah memberikan sumbangsih pada bangsa dan negara, informasi menunjukkan bahwa pada tahun 2002-2008 industri kreatif Indonesia menduduki peringkat 6 dari 10 sub sektor industri, dengan rata-rata kontribusi PDB sebesar 7,8\%. Ekonomi kreatif telah menyerap 11,8 juta tenaga kerja atau sebesar $10,72 \%$ dari total tenaga kerja nasional pada 2013, di atas target 8,35\%. Ekonomi kreatif telah menciptakan 5,4 juta usaha atau sekitar $9,68 \%$ dari total jumlah usaha nasional, serta memberikan kontribusi terhadap devisa negara sebesar Rp 119 Triliun atau sebesar 5,72\% dari total ekspor nasional. Data dari Kemenparekraf RI, bahwa ekspor karya kreatif Indonesia tengah tahun 2014 mencapai Rp 63,1 triliun atau tumbuh sebesar 7,27\% dibandingkan periode yang sama 2013. Potensi ekonomi kreatif ke depan sangat besar dan dapat menjadi kekuatan baru sebagai sumber daya yang tidak terhabiskan. Hal ini dikarenakan sumber utama adalah orang kreatif yang dapat berkembang dan menciptakan nilai tambah karena iklim yang kondusif dan akan terus tumbuh memberi kontribusi ekonomi maupun non-ekonomi (Supardi, 2017).

Kelompok PKK Kelurahan Krajan Kabupaten Klaten berada pada kondisi sosial geografis ekonomi yang startegis dengan lingkungan pasar tradisional. Jumlah anggota dari PKK Kelurahan Krajan kurang lebih ada sekitar 160 orang. Sebagian kelompok PKK ini memiliki pendapatan yang relatif masih rendah karena tidak memiliki modal atau ketrampilan lain untuk menambah penghasilan (E. S. Vh and E. Susilowati, 2016). Keterbatasan tersebut menjadikan sebagian Kelompok PKK hanya memiliki satu jenis pekerjaan dengan penghasilan per hari yang masih rendah.

Berdasarkan dari data Kelurahan Krajan diperoleh bahwa mata pencahariannya antara lain adalah sebagai pedagang di pasar, pedagang di rumah, pegawai kantor (PNS/swasta), pegawai di pasar, baby sister, pembantu rumah tangga, pengasuh anak, dan menjual minuman atau makanan, buruh di sawah, bekerja panggilan, dan lain-lain. Rata-rata penghasilan yang diperoleh adalah sekitar Rp 25.000/hari. Penghasilan tersebut masih belum ideal mengingat harga kebutuhan pokok semakin naik. Aktifitas yang dilakukan oleh Kelompok PKK sebagian besar masih belum terlalu banyak sehingga memiliki waktu longgar yang cukup. Kegiatan jual beli atau aktifitas mata pencaharian hanya berlangsung di pagi hari saja tatkala kegiatan pasar masih aktif. Pada siang atau sore menjelang malam mereka tidak memilki aktifitas tambahan, sehingga masih banyak waktu luang untuk menambah kegiatan yang dapat menambah penghasilan.

Dari analisis situasi tersebut maka ada beberapa masalah yang muncul, antara lain adalah tingkat penghasilan yang masih relatif rendah yaitu rata-rata sebesar Rp 25.000 per hari. Diperlukan kreatifitas bagaimanakah meningkatkan tingkat perekonomian atau penghasilan per hari dari Kelompok PKK Kelurahan Krajan yang tidak membutuhkan modal begitu besar tetapi dapat menghasilkan keuntungan yang relatif tinggi. Mengingat sebagian dari mereka juga sudah memiliki aktifitas atau pekerjaan yang sudah dijalankan, maka aktifitas apakah yang 
dapat dilakukan untuk mendukung Kelompok PKK Kelurahan Krajan dalam rangka meningkatkan rata-rata penghasilan per hari tetapi tidak mengubah atau mengganggu pekerjaan yang sudah dijalankan. Aktifitas ini merupakan aktifitas sampingan yang memerlukan waktu dan tenaga yang fleksibel. Kurangnya pengetahuan tentang diversifikasi suatu produk rumah tangga seperti pembuatan detergent cair dan bubuk yang sebenarnya mereka bisa membuat sendiri, maka bagaimanakah membuat produk tersebut sehingga dapat menghasilkan nilai tambahan untuk kehidupan keluarga. Diperlukan edukasi dan pendampingan bagaimana memasarkan, branding, packaging, marketting dari produk rumah tangga yang sudah dihasilkan sehingga nantinya produk tersebut bisa dijual di pasar sekitar tempat mereka tinggal dengan tampilan yang menarik dan harga terjangkau, bisa di warung-warung makan yang ada di sekitar pasar. Bahkan dapat dididstribusikan di luar daerah dengan koneksi yang sudah terjalin sebelumnya. Tujuan program ini adalah melakukan edukasi tentang pemasaran produk yang dihasilkan, mengelola sistem keuangannya serta tindak lanjut dari program agar dapat meningkatkan penghasilan dan menghasilkan aktifitas yang dapat menyerap tenaga kerja.

\section{METODE}

Tahapan yang akan dilaksanakan secara detail dalam kegiatan Program Kemitraan Masyarakat ini ada beberapa tahap. Pelaksanaan Kegiatan dilakukan dari tanggal 25 Juni sampai 10 September 2019. Tahap pertama adalah survey dan studi analisis situasi Kelompok PKK Kelurahan Krajan. Kegiatan ini meliputi pendataan jumlah anggota Kelompok PKK, mendata jenis mata pencaharian, mendata rata-rata pendapatan atau penghasilan per hari, mendata aktifitas yang sering dilakukan. Pada tahap ini dilakukan oleh Tim Pengabdian PKM dari kepakaran bidang Ekonomi sebagai analisis mata pencaharian, pendapatan rata-rata per hari dan membantu analisis kegiatan ini. Selain itu diperlukan kepakaran bidang Teknik Kimia untuk memecahkan permasalahan atau memberikan solusi tentang pembuatan detergent cair dan bubuk.

Tahap kedua adalah sosialisasi dan pendampingan pembuatan detergent cair dan bubuk. Pada tahap ini akan dijelaskan tentang pembuatan detergent cair dan bubuk. Proses pembuatan produk detergent cair dan bubuk didemonstrasikan di Kelompok PKK Kelurahan Krajan. Peserta akan melakukan praktik langsung cara pembuatan produk-produk ini. Pada tahap ini juga akan dijelaskan kegunaan masing-masing bahan yang digunakan sehingga Kelompok PKK ini dapat mengetahui dan memahami fungsinya, sifat-sifat kimiawinya, dan kebahayaanya.

Tahap ketiga adalah edukasi dari tinjauan ekonomi dan pemasaran produk. Pada tahap ini Kelompok PKK Kelurahan Krajan akan diberikan edukasi bagaimana menghitung biaya produksi, modal, laba usaha, harga jual, pembukuan keuangan, dan menghitung break even point (BEP), teknik pemasaran yang menarik, branding.

Tahap keempat adalah edukasi dan pendampingan tentang pemasaran produk. Kegiatan ini meliputi teknik penjualan online, offline, branding, packaging, dan pencarian nomor produksi industri rumah tangga. Tahap kelima adalah pemantauan berkala kegiatan pembuatan detergent cair dan bubuk. Pada tahap ini selain dilakukan pemantauan juga dilakukan evaluasi keberhasilan pembuatan produk ini.

\section{HASIL, PEMBAHASAN, DAN DAMPAK}

Program pembuatan detergent cair dan bubuk ini merupakan terobosan dan inovasi dari konsep ekonomi kreatif. Masyarakat yang semula hanya mengandalkan mata pencaharian sebagai buruh, pekerja di pasar, berdagang yang memiliki laba pas-pasan untuk mencukupi kebutuhan hidup sehari-hari, maka dengan adanya pembuatan detergent cair dan bubuk, masyarakat diberikan pelatihan, pendampingan, dan pemantauan untuk membuat produk rumah tangga pembuatan detergent cair dan bubuk. 
Proses pembuatan detergent bubuk diperlukan bahan-bahan antara lain adalah texapon bubuk, sodium bikarbonat, kaustik soda, sodium borate, dan bibit minyak wangi. Pembuatan detergent cair diperlukan bahan-bahan antara lain adalah texapon cair, natrium sulfat, camperlan, foam boaster, $\mathrm{NaCl}$, EDTA, gliserin, bibit minyak wangi, dan pewarna.

Masyarakat diedukasi bagaimana membuat produk rumah tangga tersebut, diberikan penjelasan masing-masing fungsinya dari bahan-bahan dasar pembuatannya, diedukasi tentang teknik branding, packaging, marketting, pembukuan, penghitungan modal awal, laba. Selain itu masyarakat juga didampingi dalam rangka mencari nomor ijin produksi rumah tangga sehingga mereka secara legal formal menghasilkan produk yang resmi terdaftar.
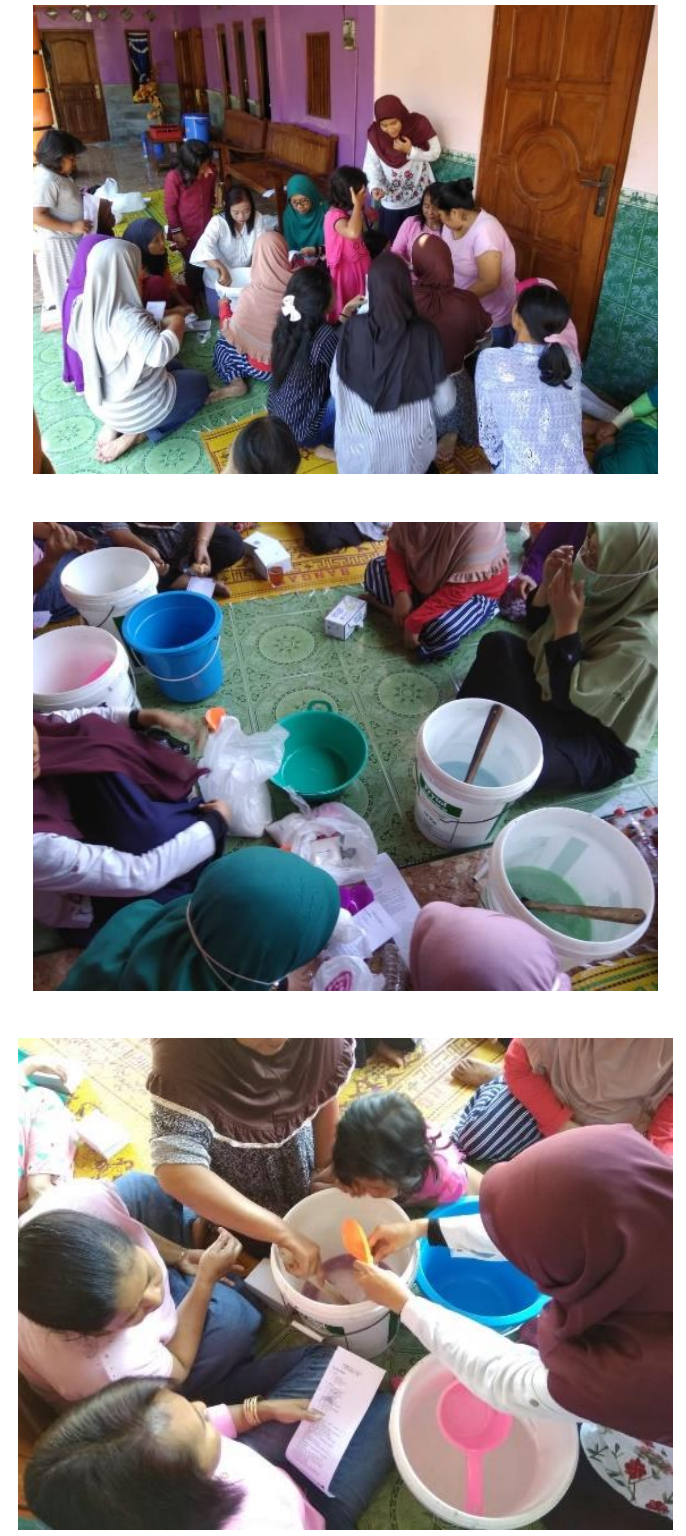
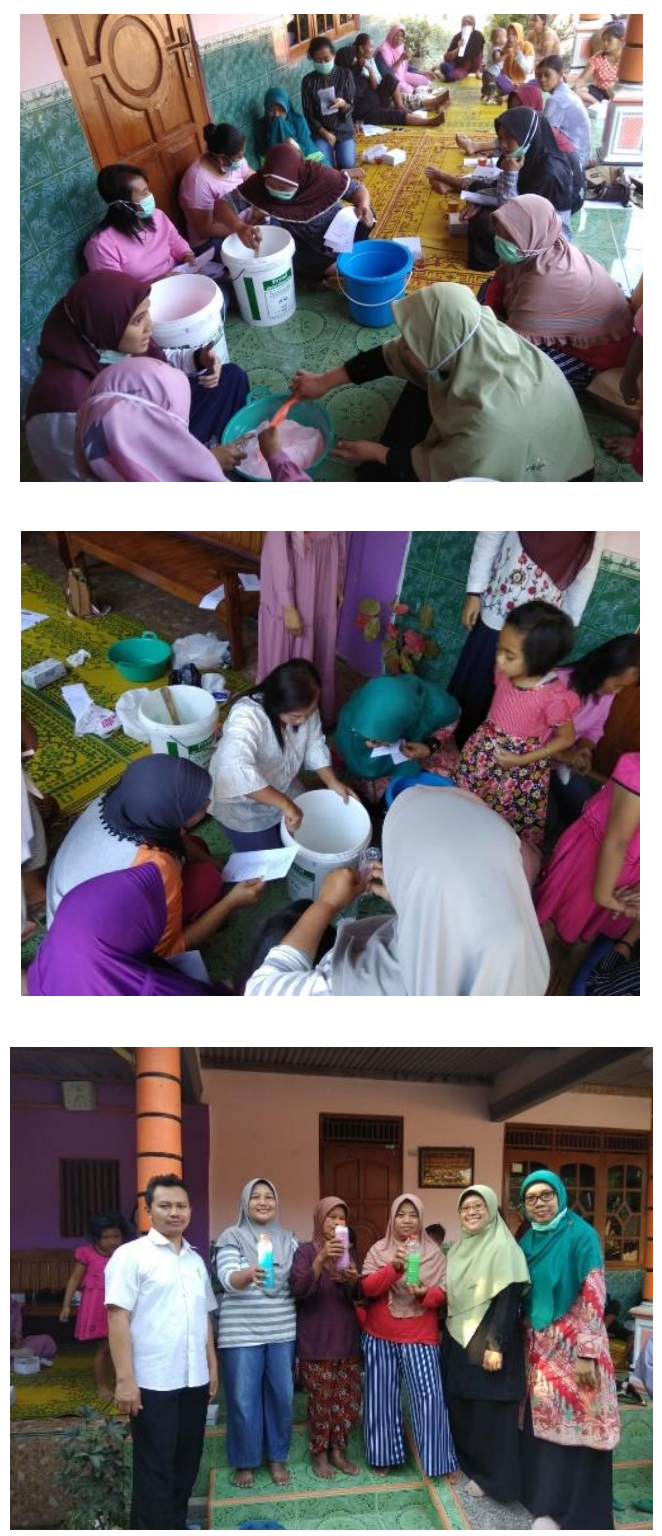

Gambar 1. Dokumentasi dalam kegiatan pembuatan detergent cair dan bubuk

Melalui program pembuatan detergent cair dan bubuk ini, kelompok PKK Kelurahan Krajan dapat meningkat pendapatan per harinya sehingga dapat memperbaiki kualitas dan ketentraman hidup. Peningkatan pendapatan ini dikarenakan ada beberapa anggota kelompok PKK yang menjual produk ini di pasar, sehingga dapat menambah pemasukan. Selain itu melalui pembuatan detergent cair dan bubuk ini maka dapat menciptakan lapangan kerja baru 
bagi masyarakat di Kelurahan Krajan. Masyarakat kelompok PKK Kelurahan Krajan. Dokumentasi kegiatan dapat digambarkan pada Gambar 1.

\section{SIMPULAN}

Ekonomi kreatif melalui pembuatan detergent cair dan bubuk dapat meningkatkan pendapatan kelompok PKK Keluraham Krajan. Kegiatan ini diharapkan akan menjadi salah satu terobosan untuk membuat produk unggulan daerah. Hal ini dikarenakan kondisi sosial ekonomi masyarakat kelompok PKK Keluraha Krajan yang dekat dengan pusat ekonomi yaitu Pasar Gabus. Kegiatan ini dapat meningkatkan pendapatan dan penghasilan sebagian masyarakat kelompok PKK Kelurahan Krajan yang mempunyai semangat dan etos kerja dalam membuat dan memasarkan detergent cair dan bubuk.

\section{UCAPAN TERIMAKASIH}

Terima kasih kami ucapkan kepada Direktorat Riset dan Pengabdian Masyarakat, Kementrian Riset Teknologi dan Pendidikan Tinggi, civitas akademika Universitas Muhammadiyah Surakarta, Universitas Sebelas Maret, Universitas Setia Budi serta Mitra PKM Kelompok PKK Kelurahan Krajan, Kecamatan Jatinom, Kabupaten Klaten Jawa Tengah.

\section{DAFTAR PUSTAKA}

E. S. Vh and E. Susilowati, (2016), Pemberdayaan Ibu-Ibu PKK Melalui Pelatihan Dan Pendampingan Produksi Sabun Dan Detergent, p. 10.

Purnomo, RA, (2016), Ekonomi Kreatif : Pilar Pembangunan Indonesia, p. 111.

Sadilah, E., (2010), Ekonomi Kreatif, Jantra, vol. V, no. 9,

Supandi, E., (2017), Analisis Keunikan Sumberdaya Dan Strategi Keunggulan Bersaing Produk Kreatif (Studi pada Saung Angklung Udjo Bandung Jawa Barat), J. Manag. Bussnies Rev., vol. 14, no. 2, 
